\title{
Traditional Dispute Resolution Mechanisms in Afghanistan and their Relationship to the National Justice Sector
}

\author{
By Julia Pfeiffer, Heidelberg*
}

\section{A. The Relationship between the formal and informal justice sector from a historical perspective}

The challenge of a parallel existence of formal and informal justice ${ }^{1}$, with the latter being more popular among the population ${ }^{2}$ in fact already existed before the fall of the Taliban regime. Looking back in history, the Afghan people have rarely relied on any governmental institution. The Afghan government either lacked authority over the whole country because of an internal or international conflict, or the formal institutions were not trustworthy for the people ${ }^{3}$. In order to better understand the parallel existence of both formal and informal institutions the following shall provide a brief overview over the Afghan legal history.

Afghanistan has always been a country with a weak centralized authority. Instead, it was fragmented into many different self-organized tribes. First attempts to establish a centrally ruled legal system were already made in the $2^{\text {nd }}$ half of the $19^{\text {th }}$ century by Amir Shayr Ali and, after the war with British India, by Amir Abd al- Raham Khan. However those early efforts to create a unique legal system for the whole country were hampered by the strong influence of the religious leaders (ulema), especially in the rural parts of the

* Julia Pfeiffer, Research Fellow, Max Planck Institute for Comparative Public Law and International Law (MPIL), Afghanistan Projects, Heidelberg, Germany; E-mail jpfeiffer@mpil.de. The author wants to thank Noah Coburn, Friederike Stahlmann, Martina Spernbauer and Sayed Hameed Zia for their very helpful comments and contributions. The expressed view is the one of the author and does not reflect the official opinion of the MPIL.

1 In the following, the terminations "formal" and "informal" justice shall mean "state" and "nonstate". The term "informal justice" is often refused by Afghan women's and human's rights organisations. They argue that the informal system does not provide justice, especially regarding the treatment of women and children and thus call the bodies of the informal system "traditional dispute resolution mechanisms". Reference in this article to "informal justice" shall be without prejudice, whether such mechanisms are providing justice or not.

2 According to the Afghanistan Human Development Report of 2007, $80 \%$ of all disputes are still settled in the informal sector, whereas only $20 \%$ are brought before court (Afghanistan Human Development Report 2007, Bridging Modernity and Tradition: Rule of Law and the Search for Justice, p. 91). However this allocation differs in other studies. Although it is difficult to make an accurate evaluation, the general opinion indicates, that the majority of all disputes have not been decided upon in the formal sector.

3 Tomas Barfield, On Local Justice and Culture in Post- Taliban Afghanistan, Connecticut Journal of International Law 17 (2002), p. 439. 
country ${ }^{4}$. Nevertheless Amir Abd al- Raham Khan managed to codify the court system and create a kind of formal order in some parts of the country, by strongly relying on Islamic notions of justice and Shari' $a$ law doctrine ${ }^{5}$. However, beside the formal system, an informal system based on customary law and tribal justice mechanisms was always existent. Although the most parts of Afghanistan were Muslim and thus were expected to accept Shari'a law as legal basis, the Pashtun tribes in practice mostly adhered to their pre-Islamic practices and customs ${ }^{6}$.

Abd al-Raham was succeeded by his son Amir Habib-Allah, who continued his father's efforts to islamize and centralize the judicial system. However the mullahs and elders persisted on their role as interpreters of the laws in arbitration and informal justice proceedings. Thereby they managed to maintain their power within the tribes ${ }^{7}$.

Another step towards the centralization of the justice sector was the enforcement of the first Afghan Constitution in 1923 under Amanullah Khan. The constitution provided detailed regulations for the organization of the courts and prohibited the establishment of any dispute settlement institution outside the formal court system ${ }^{8}$. Amanullah Khan furthermore promoted the codification of new regulations deduced from Shari'a law. Those developments however led to strong opposition and rebellion, especially among the Pashtun tribes, which feared the loss of authority and thus argued that the new laws of the state would violate Islamic law. The resistance of the tribes finally resulted in the collapse of Amanullah Khan's regime'.

His successors followed the policy of rapprochement towards the tribes since the state's authority was limited to the urban areas only. Yet the constitution of 1964 aimed again at the promotion of centralized law which hereupon led to the extension of State power and the application of state laws even into the rural areas. In some provinces for example, centers of administration were established and local officials appointed in order to create a linkage between the central government and the provinces. Nevertheless, the informal system remained more prominent and 75 per cent of all cases were solved by such dispute settlement institutions ${ }^{10}$.

The expansion of the State's authority to the whole country stagnated with the outbreak of the Soviet- Afghan war (1979-1989) and the subsequent civil war which lasted until the

Amin Tarzi, Historical Relationship between State and Non-State Judicial Sectors in Afghanistan; http://www.usip.org/files/file/tarzi_paper.pdf, p. 3.

5

Tarzi, note 4, p. 6.

Tarzi, note 4, p. 8 .

7 Tarzi, note 4, p. 10.

8

Articles 50-57 Afghan Constitution (1923).

9 Tarzi, note 4, p. 11.

10

Tarzi, note 4, p. 12. 
end of the Taliban regime. During this period of time, formal government institutions especially in the rural areas ceased to exist.

The lack of control of the central government led again to increasing importance of the local assemblies and rise of their power. Yet some institutional gaps were filled with young armed military commanders, mostly leaders of resistance groups. Those warlords often exercised state functions, like decision-making in local administrative matters or enforcement of their own rules.

The resistance commanders in turn feared the rising power of the clergy. This group contained inter alia former governmental judges who continued working in that position and promoted Islamic law even after the central government collapsed ${ }^{11}$. The law implemented by the ulema was applied even in the rural areas of the country, handling most affairs concerning the community and thus gained increasing importance in the society. In the Pashtun regions however, adherence to customary law, namely the Pashtunwali was still dominant $^{12}$.

The power and influence of the Afghan clerics finally reached the climax when the Taliban movement assumed control over the most parts of the country. The Taliban understood themselves as Islamic movement and alleged to rely on Islamic law. Yet the majority of them was poorly educated or even illiterate and thus their interpretation of Islam occurred without any academic reference to the Islamic law discourses or jurisprudence. Therefore, the Taliban's notion of Shari'a law did not earn much respect in the Islamic world $^{13}$.

The Taliban maintained the old governmental courts in Kabul but established also new courts in 13 provinces which were under the control of Kandahar, the seat of Taliban leader Mullah Omar. All courts were ordered to strictly apply Shari'a law. The decisions released by Taliban courts however fell short of both substantive and procedural considerations of Islamic legal doctrines and were especially hallmarked by draconian punishments like stoning for adultery or other public executions. Although such punishments, called hudud, are sanctioned in the Quran, they had been abolished in Afghanistan already long before the Taliban came into power.

Tomas Barfield, Neamat Nojumi and J Alexander Thier, The Clash of Two Goods-State and NonState Dispute Resolution in Afghanistan, http://www.usip.org/files/file/clash_two_goods.pdf, p. 13.

Tomas Barfield, Afghan Customary Law and Its Relationship to Formal Judicial Institutions (2003), http://www.usip.org/files/file/barfield2.pdf, p. 32. The concept of Pashtunwali will be explained further below.

According to high-ranking Egyptian clerics who visited Mullah Omar in 2001, trying to convince him, that the destruction of the Bamyan Buddahs is not required by Islamic law, the Taliban's "knowledge of religion and jurisprudence is lacking because they have no knowledge of the Arabic language, linguistics and literature and hence they did not learn the true Islam". Therefore, the knowledge of jurisprudence would be incomplete and thus the Taliban would not be able to formulate rulings backed by theological evidence. (Barfield, note 12, p. 35). 
Although the Taliban opposed the Pashtun tribal system and customary laws their interpretation of Shari'a law was indirectly influenced by the Pashtunwali. Most of the leaders were educated in Pakistani madrassas and such schools could not provide any advanced religious training in Arabic, which is however a fundamental requirement for understanding Qur'an and Sunnah, customary law principles, especially those of the Pashtunwali, were merged with religious law ${ }^{14}$.

\section{B. Current Situation}

One objective of the international supported state-building mission in Afghanistan is to strengthen the formal justice system. The promotion of the rule of law in post-Taliban Afghanistan was provided for in the Bonn Agreement, the Afghanistan Compact and the Afghan National Development Strategy, the most recent state-building policy of the country. Despite various efforts to strengthen the formal justice system, prevalence over the informal system still has not been achieved.

\section{The Situation of the Formal Justice Sector}

According to the Afghan Human Development Report of $2007^{15}$ examining the status quo of the Afghan Judiciary, the formal justice sector faces many grievances.

Nevertheless, some reformations took place in the last years. For example, the court system has been re-established and is now regulated by the Law on Organization and Jurisdiction of Courts of the Islamic Republic of Afghanistan ${ }^{16}$. It compromises three levels of jurisdiction, with the Supreme Court on the top and a Provincial Appeal Court in each province on the second level. However there are not yet enough courts on the primary level within the districts, and those existing suffer from a deficit of personal resources and infrastructure. Although Article 2 of the Law of the Organization and Authority of Courts constitutes, that "[t]raveling courts may be established when needed, on recommendation by the Supreme Court and approval of the President", until now no such courts have been established $^{17}$. Therefore, access to the formal system is often difficult, in the rural areas even impossible due to the lack of formal justice institutions. Moreover, many people are not able to file a claim due to illiteracy. This problem is especially valid for women, whose illiteracy rate is about $90 \%$ in the rural areas ${ }^{18}$. Women generally have greater difficulties

14

15

16

17

18

Barfield, note 12, p. 35.

Afghanistan Human Development Report 2007 (note 2), Chapter 3, p. 53-64.

Official Gazette No. 851, published 31 Sawar 1384 (May 21, 2005).

However, in some rural areas without courts, ISAF has begun to employ and support prosecutors constituting a new development in the civil-military relationship.

UNAMA/ OHCHR: Silence is Violence - End the Abuse of Women in Afghanistan, Kabul 2009, p. 8, with reference to UNAMA press conference on 20 April 2009, online transcript: http://unama.unmissions.org/Default.aspx?tabid=1761\&ctl=Details\&mid=1892\&ItemID=3584. 
to access the formal justice sector than men. They often have no own income and thus cannot provide the necessary financial means to pay for the procedure and the bribes for the judges. Furthermore, women are normally not able to leave the house without their husband's or family's permission, especially in the rural areas. It is moreover considered inappropriate in Afghanistan when a woman appears at a court alone. Women trying to take legal action anyway often face abuse, sexual harassment and rejection by both police and court staff. They thus need their family's support in terms of filing a claim before a court ${ }^{19}$. Yet this requirement hinders most women in taking legal action against for example domestic violence.

There are also shortcomings in the legal education of judges. The current formal legal order in Afghanistan is a combination of both Shari' $a$ and civil law. It is mainly copied from the Egyptian legal system, being a moderate interpretation of Islamic law, influenced by French law $^{20}$. However, the legal education on Afghanistan is divided into Shari ' $a$ faculties and faculties of Law and Political Science and graduates from both faculties are entitled to work for justice institutions. Beside, some staff members come from (non-state) religious institutions, like madrassas mostly in Pakistan, where no legal education takes place. Although the curricula of at least the law and Shari ' $a$ faculties is envisaged to contain mainly the same subjects, the education still differs ${ }^{21}$. Most Afghan jurists thus studied either civil or Islamic law and are therefore not adequately educated to appropriately deal with the whole Afghan legal system.

Although both institutional and personal independence of the judiciary is stipulated in Article 116 Afghan Constitution, the safeguards established in the constitution or the Law on Organization and Jurisdiction of Courts of the Islamic Republic of Afghanistan are not yet sufficiently implemented in practice. Therefore due to the general lack of security, judges are often hindered to act or decide impartially.

Furthermore, proceedings in the formal system often take considerable long time, even up to several years, and are too expensive for many potential claimants.

Courts are facing a huge backlog of cases since long-serving judges are not willing to hand over their files to recently appointed judges, who in fact would be available and ready

According to the Human Development Index of 2009, the literacy rate among adults in Afghanistan is only $28 \%$ (http://hdrstats.undp.org/en/countries/country_fact_sheets/cty_fs_AFG.html).

For a more comprehensive overview see the studies of Human Rights Watch, Women's Rights in Afghanistan, Section VI: Guilty on Arrival: Women's Access to Justice, Kabul December 2009, pp. 62 and Women and Children Legal Research Foundation (WCLRF), Women's access to Justice - Problems and Challenges, Kabul 2008; http://www.wclrf.org/English/eng_pages/ Researches/Women_a_t_Justice/WATJ.pdf .

Afghanistan Human Development Report 2007 (note 2), p. 69.

National Justice Sector Strategy (NJSS), Chapter III, p. 5: Legal Education and Training, Section B.1: Developing Law and Shari 'a Faculties. 
to take over pending cases. However the former want to keep the cases for financial reasons, for example because of bribes they may earn with those cases ${ }^{22}$.

Corruption is widespread in the judiciary, increasing the costs for the claimants. This may be traced back inter alia to the low salaries of the staff ${ }^{23}$, however it is questionable whether corruption would completely disappear in light of higher salaries ${ }^{24}$. All those grievances contribute to the preference of the informal justice sector, especially in rural areas, but also in the cities. This shall not imply however, that the informal institutions are for free. Yet the costs or bribes are not that high than for the formal institutions. Moreover, a resolution for a dispute can be found within a shorter time ${ }^{25}$.

\section{The Situation of the Informal Justice Sector}

The informal justice sector cannot be described as a uniform system, because its characteristic varies from region to region, between the districts or villages and even differentiate among the social fields ${ }^{26}$. The following therefore provides only a rough overview over the mechanisms and procedures of informal dispute settlement mechanisms in the Pashtun areas of the country and in Bamyan province.

22

For example, refugees who lived abroad and returned after the end of the Taliban regime often

have a different understanding of "law" than those who stayed in the region during the wars. (Personal Interview, November 2010, Heidelberg).

Personal Interview, 17 April 2010, Kabul.

According to a prosecutor in Paktika, the wages for staff in the judiciary varies between 60 and 150 \$ per month. (The Liaison Office, Linkages between the State and Non- State Justice Systems in Eastern Afghanistan- Evidence from Jalalabad, Nangarhar and Ahmad Aba, Paktia, 2009, p. 10).

24 For example, although the salaries for police officers have been raised recently, corruption is still common, and said to be even worse than in the judiciary. This leads to the presumption, that higher loan alone is not an effective measure against corruption. Instead, the whole system must get rid of the prevailing culture of corruption.

It may be arguable if those institutions in fact settle the dispute, or if they rather "manage" it. However at least they claim to function as a settlement mechanism. (Personal interview, November 2010, Heidelberg). 


\section{Informal Dispute Settlement in the Pashtun areas ("Pashtunwali") 27}

Most research on customary law and informal justice has been undertaken in the Southern and Eastern parts of the country, which are mainly settled by Pashtuns. The applied framework of customary rules in Pashtun communities is called Pashtunwali. Among the various concepts of informal justice in Afghanistan, the Pastunwali is probably the most famous one. It is an ethical codex and means literally "the way of the Pashtuns",28. The main principles on which the Pashtunwali is grounded are personal honor (ghayrat), revenge (badal), hospitality (melmastia) and sanctuary (nanawati) ${ }^{29}$. All behaviors of the Pashtun community are derived from those principles ${ }^{30}$. The informal dispute settlement takes place in socalled shuras or jirgas ${ }^{31}$, whose members mainly serve as mediators or arbitrators. Informal justice mainly aims at reconciliation for the purpose of pacifying the community, which however may also include punishment of the guilty party. Before commencing a jirga, the mediators/arbitrators are normally approved by the disputants (waak). Both parties have to

The following elaboration is based on a study conducted by The Liaison Office (TLO), an Afghan non- governmental organization (http://www.tlo-afghanistan.org/). In order to understand, how state and informal justice system function and how they interact with each other, TLO performed field-research between February and May 2009 in Jalalabad, the provincial capital of Nangarhar and Ahmad Aba, a rather rural district of the province Paktika. Although this study is not representative for all Pashtun areas of the country since security situation is rather stable in both regions, it highlights at least the core principles of informal justice on the basis of the Pashtunwali. Nevertheless, the mentioned mechanisms assumable differ in other regions.

Palwasha Kakar, Tribal Law of Pashtunwali and Women's Legislative Authority, http://www.law. harvard.edu/ programs/ilsp/research/kakar.pdf, p. 3.

Barfield, note 12 , p. 5.

The concept of revenge follows the idea "an eye for an eye, a tooth for a tooth", which means, that if a family member was killed by another tribe, the victim's family normally seeks revenge in killing a member of the perpetrator's tribe. Therefore, blood feuds are fairly common, and the wish to take revenge even outlasts the prison sentence of the offender. The following incident underlines this attitude: A man killed the man of another tribe, he was subsequently adjudged to pay compensation in money to the victim's family and was sent into prison for several years. After his release, a relative of the victim took the whole sum of money to the offender, gave it back and then killed him. (Personal interview, 17 April 2010, Kabul).

The concept of hospitality implies, that a guest has to be offered the best possible for example in terms of food, shelter or clothing. Furthermore, the host has to protect the guest. In return, the guest provides the same for the host on another occasion. Taking revenge is subordinated to the principle of hospitality. Therefore, a host would even have to accommodate an enemy and during the time of accommodation would not be allowed to take any revenge (Barfield, note 12, p. 7).

Those crucial principles are driven by the role of personal honour (ghayrat). Dishonoring behavior evokes shame and can lead to acts of revenge. A woman has to preserve the honour of her male relatives. If she fails to do so, her relatives are allowed to kill her in order to restore their honour. Women are thus mainly excluded from public live for limiting the risk of endangering the honour of her male relatives.

Since those terminations can be used interchangeable, the following sections will refer only to "jirgas". 
provide machalgha which are goods with an equivalent value to the case. They shall guarantee the acceptance and implementation of the jirga's verdict. In most cases, the outcome is recorded. The copies remain with the jirga and the parties and are sometimes send to the local government ${ }^{32}$. The amount of jirga members and the duration of the trials depend on the cases to be solved. The members are normally well-reputated or powerful men from the community; they are either selected by their tribes or have been appointed by the district governor $^{33}$. However, it should be the disputant's voluntary decision to accept the jirga's authority, following the concept of Pashtunwali on individual autonomy. In practice though, social settings will probably not allow any refusal of the jirga ${ }^{34}$. The outcome of the jirga in general rather aims at reconciliation than at punishment. Instead of defining the guilty party, the jirga members try to maintain harmony within the community and an ultimate settlement of the dispute. In consequence however, the jirga is simply confirming the power constellation between the parties, meaning that the more powerful party will nevertheless profit out of the case. Thus from an objective point of view, the outcome may look unfair. On the other hand, if the jirga members explicitly accused the offender, they would run the risk of insulting the latter, evoking more violence and instability within the community ${ }^{35}$. The jirga's decision must be accepted by all parties in order to restore peace and harmony within the community. Since peaceful co-operation has highest priority, dispute settlement like it is done in the informal system is more accepted by the Pashtuns than an order of punishment by the state without consent or compromise ${ }^{36}$.

Although being strongly opposed by human rights organizations, ordering bad37 or the exchange of girls is still common among some tribes, especially in terms of serious cases like murder. The marriage between the victim's and the offender's family shall link the two families together, support the reconciliation process and thus settle the dispute. In this regard, the informal system privileges wealthier families, who can refuse to give a girl as

The Liason Office, note 23, p. 12.

In the province Paktia for example, there exist different shuras or jirgas on different levels, starting from the village level and going up to the district level. Such a district shura also serves as a linkage between the government and the people of the region. (The Liason Office, note 23, p. 13).

Personal Interview, November 2010, Heidelberg.

For example, if a commander steals ten hectares of land from a poor man, the jirga might make the commander to give back only seven hectares and keep three. Otherwise, the commander very likely would have lost his face, thus felt insulted and started a feud against the jirga members which probably would lead to more violence within the community.

The Liason Office, note 23, p. 25.

$\mathrm{Bad}$ is the forced marriage of a woman from the offender's family with a man from the victim's family. The woman is thus used as compensation for the committed crime. The supporters of this practice often argue that due to the intermarriage the wife can influence her husband not to kill members of her family. It is doubtful however, if a wife actually have this kind of influence on her husband in such a situation. 
compensation but pay the pride price for another marriage instead, whereas poorer families do not have such an option ${ }^{38}$.

\section{Informal Dispute Settlement in Bamyan Province}

The province of Bamyan is located in central Afghanistan and part of the so-called Hazarajat. It is mainly settled by Hazaras, the third largest ethnic group in the country. The Hazaras belong to the Shi'a sect, which is predominant in Iran whereas the majority of the population in Afghanistan is Sunni. Bamyan is a largely rural province and especially in the rural parts, most of dispute settlement occurs within the villages. On the village level, decisions are made in one or several meetings of a jalasa, which consist of well-known, trustful but also powerful men and sometimes women ${ }^{39}$, called "white-beards" or "widehairs", the disputants and witnesses. The jalasas aim at maintenance of community honor and avoidance of the dispute's spreading. Since the community within the villages is interwoven, disputes may quickly affect third-parties, possibly resulting in a larger and violent conflict. Numerous un-resolved disputes in a village furthermore can damage the reputation of the community's elders, and thus, settling a dispute means also preservation of personal honor of the jalasa's members ${ }^{40}$. Some cases are taken from the villages to the district level, namely to the district governor (woliswal) and the ulama shura for settlement. The woliswal acts on the one hand as a connector between other state actors, such as the police, courts and prosecutors, and transfers the cases to those institutions. On the other hand, he himself may be involved in dispute settlement as decision-maker and, furthermore, is responsible for registration of the jalasas' outcomes in the villages ${ }^{41}$. The woliswal sometimes refers disputes to the ulama shura, which consists of Islamic scholars resolving disputes on the basis of Ja'fari jurisprudence ${ }^{42}$. In the capital, Bamyan city, the state is quite

Nevertheless, the tradition of bad has been successfully abolished in other areas. For example in Ahmadaba the elders decided upon an agreement already years ago, that, instead of giving women or girls the compensation shall be paid in money. In recent times and due to the high poverty rate, the agreement has been changed again, now stipulating the exchange of land (Personal interview, 17 April 2010, Kabul).

Although women's access to such jalasas is rather restricted, women nevertheless sometimes participate in decision-making, especially in terms of inter-family disputes. However they are excluded from decision-making in big disputes, as serious domestic violence, murder, big fights or rape (Deborah J. Smith, Shelly Manalan, Community-Based Dispute Resolution Processes in Bamyian Province, 2009, p. 14). Some of those inter-family disputes never even reach men but 40 are settled by women alone (Personal Interview, November 2010, Heidelberg). Smith and Manalan, note 39, p. 15.

41 Smith and Manalan, note 39, p. 19.

42 Ja'fari fiqh is the Shi'a school of Islamic law. Followers of the Shi'a sect have the constitutional right to solve their disputes in accordance with Shi'a jurisprudence (Article 131 Afghan Constitution). 
strong and many parties bring their disputes before a court ${ }^{43}$. Nevertheless informal mechanisms are also popular, mostly for practical reasons. Especially from the remote villages it can take several hours or even days to reach the woliswal's office, and the journey is often too expensive for the disputants. Again, corruption is another big issue, excluding poorer families from the option to access the formal sector, since they lack money for paying bribes ${ }^{44}$. Another motivation for dispute settlement in a jalasa is the knowledge of the white-beards about the village and the community, which helps to understand the background of the dispute. Since institutions on the district level are often lacking this knowledge, people believe that the judges will have to rely on the white-beards opinions anyway. Also sensitive cases like disputes within a family or with women involved are often sent back from the governmental actors to the jalasa because the state actors fear that any decision made by a formal institution may increase the animosity between the disputants, leading to an expansion of the conflict to other relatives, and hence the community ${ }^{45}$.

Comparable to the jirga's decisions in the Pashtun areas, a jalasa tries to find a solution, which ultimately ceases the dispute and thus maintains the harmony in the community. In order to resolve a dispute, the jalasa applies either Shari ' $a$ or customary law. The members of a jalasa well differ between the application of Shari'a law or customary law, considering customary law as the more flexible and thus practical system of justice ${ }^{46}$. However the disputants are said to have the choice between decision-making on the basis of customary law or Shari 'a law ${ }^{47}$. The guilty party normally has to pay compensation to the injured party, which is foreseen in the Shari'a and called deya. However, the way of compensation as stipulated in Shari'a law is often not affordable and inappropriate for the relatively poor Hazara community. Thus jalasas converted deya into a more affordable way of ompensation. Such "customary deya" may consist of an apology and a slaughtered sheep or a smaller amount of compensation as stipulated in Shari'a law ${ }^{48}$. Although this may be advantageous for the poorer people, denying compensation for the sake of harmony within the community is a rather pragmatic solution which can constitute a further violation of the victim's rights.

\section{Linkages between the Formal and the Informal Sectors}

In recent times, there have been some developments regarding the co-operation of formal and informal institutions. Although this is not valid for the whole country, the informal sector became increasingly formalized in some parts, for example in terms of registration of

43

44

45

46

47

48

Personal interview, November 2010, Heidelberg.

Smith and Manalan, note 39, p. 25.

Smith and Manalan, note 39, p. 26.

Smith and Manalan, note 39, p. 38.

Smith and Manalan, note 39, p. 38.

Smith and Manalan, note 39, p. 40. 
jirga members with the district or provincial government. Moreover, many judges refer their civil cases to the informal system for mediation, following the quranic principle of sulh, according to which conciliatory justice has to be preferred ${ }^{49}$. Afterwards, the outcome of such proceedings is generally registered by a judge and thus formalized. However, since no overall standardized way of registration has been developed yet, the formalization of arbitration proceedings differs between the districts. Yet disputes are not only referred from the formal to the informal sector; when a dispute cannot be solved by a jirga the case is transferred to a court. This applies especially to criminal cases ${ }^{50}$. Nevertheless, several criminal cases remain in the informal sector and are settled there, violating the state's monopoly to punish.

The competences and responsibilities of the formal and informal institutions are sometimes regulated in agreements between the informal local and the district government. Such agreements entitle the tribes to some autonomy, when, in turn, they provide support to the government that is unable to control the area. Furthermore, foreign armed forces sometimes get involved in dispute resolution as well. For example in Helmand, the US Marines conducted several missions, searching for insurgents in the nearby villages. As the tribes realized, that the Marines where arresting suspects, they started to bring their "ordinary" criminals to the US-led Forward Operating Bases (FOBs) for prosecution. Since the US Army did not really know how to deal with those cases, the management decided to establish a jirga, including both Marines and elders from the region. The main task of this jirga was to decide, if the dispute can be settled informally or if the offender shall be brought to the next court in Lashkar Gah, the provincial capital ${ }^{51}$. Another linkage between the formal and the informal sector are provincial councils, which establishment is stipulated in Article 138 Afghan Constitution. They shall consist of members having been elected by the residents of the particular province. The task of a provincial council is inter alia giving advice on important issues falling within the domain of the province ${ }^{52}$. Such provincial councils get increasingly involved in the settlement of disputes as well, pursuing the Article 4 (3) Law on Provincial Councils ${ }^{53}$.

Sulh which literally means peace is a concept of Shari 'a law, referring to the mediation of disputes (The Liason Office, note 23, p.19).

The Liason Office, note 23, p. 20. Article 139 Afghan Constitution.

53 See AREU Briefing Paper: Provincial Governance Structures in Afghanistan: From Confusion to Vision?, May 2006, p. 6 Box 2. 


\section{The Role of Customs in the Contemporary Afghan Legal System I. Application of Customs by the Courts}

The constitution of 2004 is the supreme law in Afghanistan and thus the starting point in order to find out the role of customs in the Afghan legal system.

Article 130 (1) Afghan Constitution (AC) reads: "In cases under consideration, the courts shall apply provisions of this constitution as well as other laws (qanoon)". Article 94 AC clearly states, what "law" in this understanding means, namely "[1]aw is what both Houses of the National Assembly approve and the President endorses unless this Constitution states otherwise". Therefore, custom is no "law" in the sense of Article 130 (1) AC and is thus not applicable by the formal courts. If there is a legal gap, the courts are held to apply Shari'a law, namely Hanafi fiqh ${ }^{54}$ (Article 130 (2) AC). For the Shi 'a minority of the country Article 131 AC provides an exception of this rule. The courts are held to apply Shi 'a jurisprudence in cases involving personal matters of Shi'a followers. Those have now been codified in the controversial Shiite Personal Status Law ${ }^{55}$. In terms of legal gaps in other matters, the courts are held to apply Shi'a jurisprudence instead of Hanafi fiqh. The differentiation between codified law and Islamic jurisprudence is also reflected in the Afghan Civil Code (CC) ${ }^{56}$. Article 1 (2) CC stipulates that in cases of a legal gap within the law, the courts shall apply Hanafi jurisprudence. However, Article 2 CC stipulates, that in cases where there is no provision in the law or in the fundamental principles of the Hanafi jurisprudence, the courts can apply general customs ("urf-e u'momi) in order to make a decision. Yet, the applied custom must not contradict the provisions of the law or principles of justice." ${ }^{, 57}$ Consequently, according to the Civil Code courts in civil cases can apply custom in terms of legal gaps, albeit only as a last solution. One may thus argue that Article 130 (1) AC opens the door for the application of customs by courts, since the Civil Code is another "law" in this sense.

However, the Constitution itself is silent about this option. It moreover mentions only Hanafi fiqh or Shi'a jurisprudence respectively as subsidiary means. Thus pursuing the two principles of lex posterior derogat legi priori and lex superior derogat legi inferiori one can conclude, that since the constitution does not mention custom as applicable in terms of legal gaps, Article $2 \mathrm{CC}$ is obsolete. Courts therefore cannot apply custom in civil cases. Regarding the applicability of customs in criminal law cases, the constitution is clearer: pursuing Article 27 (1) AC, a deed is only considered a crime if this is promulgated by a law having been enforced at the time of offence. Paragraph 3 furthermore rules that no one

Hanafi fiqh is one of the four schools of Islamic jurisprudence, and is the traditionally applied school in Afghanistan. Shiite Personal Status Law, Official Gazette No. 988, published 5 Assad 1388 (2008).

Civil Law of the Republic of Afghanistan (Civil Code), Official Gazette No. 353, published 15 Djadi 1355 (1977)

57

English translation revised by the Afghanistan Rule of Law Project (AROLP) / USAID, 2006. 
"shall be punished without the decision of an authoritative court" and in accordance with the provisions of the law. Thus, customs must never be taken into consideration by a court in terms of criminal law matters.

\section{Differentiation: Customs and Islamic Principles}

The Afghan Constitution refers to customs only in one provision, namely Article 54. The provision stipulates that " $[t]$ he state adopts necessary measures to ensure (...) the elimination of traditions contrary to the principles of sacred religion of Islam". Therefore, the state has the obligation to abolish at least those customs harming the "physical and spiritual health of the (...) child and the mother" and which violate the "principles of sacred religion of Islam". This phrasing is not very precise though and requires some interpretation, what Islamic principles are actually meant. A similar wording can be found in Article 3 AC according to which "no law can be contrary to the beliefs and provisions of the sacred religion of Islam". Compared to the constitutions of other Islamic republics like Pakistan or Iran, no special definition of this termination is provided in the Afghan Constitution. The term could include the Shari 'a strictu sensu, that is the Qur'an and the Sunnah, or in a narrower interpretation only refer to fiqh, namely the Islamic jurisprudence of a particular school of Islamic law. As already mentioned, Hanafi fiqh was traditionally the applied school of Islamic law among the Sunni majority in Afghanistan, whereas the Shi'a followers used to apply Ja fari fiqh and the Afghan Constitution refers to both schools of Islamic law as subsidiary sources of law. The wording of Article 3 AC however allows for a broader interpretation, since Hanafi figh or Shi'a jurisprudence are not explicitly mentioned. If the constitution-makers would have intended a reference only to the Islamic legal doctrines used in the country, they probably would have enshrined their intention in Article 3 AC, like they explicitly did in 130 (2) and 131 AC. It can therefore be perceived, that Article 3 AC refers to those principles being uncontested among all different schools of Islamic law ${ }^{58}$. In order to keep a coherent line within the constitution the same conclusion shall be made regarding Article 54 AC. Therefore, the State must take measures to abolish such customary laws which are in breach of Shari'a law in general, irrespective of any specific Islamic jurisprudence. In conclusion, those customs not in conformity with Shari 'a strictu sensu must be abolished. However this obligation may be challenging since the boundary between customs and in particular Islamic jurisprudence blurred over the years, leading to an often wrong perception about what is actually said in Shari'a law and what is mere custom. Therefore people continue with their habit in firm conviction that they are acting in accordance with Shari'a law ${ }^{59}$. Examples in this regard are for instance deprivation of girls from education, forced marriage or the role of women in the public sphere.

For further details see Ramin Moschtaghi, Max Planck Manual on Afghan Constitutional Law, Volume I: Structures and Principles of the State, Heidelberg/Kabul 2009, p. $32 \mathrm{ff}$. 
Furthermore, although polygamy is permitted in Islamic law, some strict conditions must be fulfilled. Although those conditions are mentioned in Article 86 Civil Code they are often ignored in the country. Therefore, a first step for the fulfilment of the Article 54 obligation would be to clearly distinguish custom and Islamic law.

\section{The Relationship between Custom, Islamic Law and Human Rights}

Considering only Islamic law in this regard is not enough though. Moreover, according to Article $6 \mathrm{AC}$, "the state is obliged to create a prosperous and progressive society based on social justice, protection of human dignity [and] protection of human rights (...)". Concerning the protection of human rights, Article 7 Afghan Constitution states, that "the state shall abide by the Charter of the United Nations, international treaties, international conventions that Afghanistan is part to, and the Universal Declaration of Human Rights". Thus, the Afghan state is obliged to create an environment in accordance with international human rights standards. Consequently, customs violating this standard must also be eliminated. In conclusion, customs are not recognized as formal law and thus the courts shall not apply any customs in terms of legal gaps. Moreover, pursuing Articles 6, 7 and 54 Afghan Constitution, the Afghan State must eliminate those customs being in breach of international human rights treaties and Shari'a law. In order to fulfil its duties, the Afghan State must ensure that any contradictory customs are not applied anymore, neither by a state or non-state dispute resolution mechanism. Therefore, attempts are underway, trying to create a formal linkage between the state and non-state justice sectors. The attempts are aiming on the one hand at a better control of the informal institutions and on the other hand at an improvement regarding access to justice all over the country.

\section{Recent Developments: "The National Policy on Relations between the Formal Justice System and Dispute Resolution Councils"}

Overcoming the gap between formal and informal justice in Afghanistan and creating a linkage for better co-operation has been envisaged by the Afghanistan National Development Strategy (ANDS), the National Justice Sector Strategy (NJSS) and the National Justice Program (NJP). All three documents mention the necessity to draft a national policy "for improved links between formal and informal justice sectors and oversight of the informal by the formal" ${ }^{60}$. Accordingly, a working group was established, composing representatives of the Ministry of Justice, the Supreme Court, the Afghan Independent Human Rights Commission and the Ministry of Women Affairs. This group was supported by nongovernmental organizations as well as international institutions and chaired by the Deputy 
Minister of Justice. In a longer procedure, the working group drafted a national policy, stipulating the relationship between the formal and the informal justice sector. According to this policy, the informal justice institutions ("dispute resolution councils") should work freely and without any interference of "oppressive actors". However, the disputants shall voluntarily decide to address such an institution and to recognize its authority and its decision. Furthermore informal institutions are not authorized "to detain any person".

In order to "increase access to justice", the policy proposes to formally recognize informal justice institutions by the formal system and to register their decisions, assumed they are not contravening Shari'a law, the constitution or other Afghan national laws and international human rights standards. For this purpose "such mechanisms' compliance" with the above mentioned laws should be improved and accountability of informal justice mechanisms be ensured. According to the policy, a formalized registration of all decisions prevented any renewal of the already settled dispute since the disputing or third parties were able to get aware of the dispute's outcome.

Regarding the distribution of jurisdiction, the policy proposes that the informal justice system "may consider civil cases", as long as the government is not a party to the dispute, or the exclusive jurisdiction of the formal system is designated by law. Prosecution of criminal cases though should be sole jurisdiction of the formal system. However the policy points out that with the consent of the victim "petty criminal cases" may be transferred by a formal institution to a dispute resolution council in order to reconcile the dispute in accordance with the law. The informal institution however is not authorized to impose imprisonment or fines, whereas it could impose "compensation or other civil disciplinary sanctions". The policy furthermore especially focuses on vulnerable groups, namely women and children. Regarding women for example, the policy states that "[b]oth the formal and informal dispute resolution councils must refrain from any action (...) that further victimizes or marginalizes women". Accordingly, women should be enabled to access and participate in both formal and informal systems, with their safety and confidence being ensured. In order to strengthen women's rights in Afghanistan, the policy proposes to increase the awareness of decision makers within both the formal and informal system "of the Constitution, (...) women's legal rights within Islam, Afghan law and international human rights standards". Bad and other practices which are inconsistent with Shari 'a law, domestic law and the constitution should be abolished.

Since children's rights are also often infringed, the policy recommends the improvement of access to justice for this group and to increase the awareness of decision makers in regard to children's rights. Furthermore, formal and informal justice institutions should better co-operate in the handling of cases involving children, regardless child victims or alleged child offenders. The policy moreover recommends the revision of resolution councils' decisions by the formal justice system or another dispute council. On the other side, if parties have voluntarily agreed to the jurisdiction of an informal institution, the arbitration outcome is binding and must therefore be observed as long as exceptional circumstances like "coercion, fraud, duress, corruption, violation of human rights and Afghanistan's laws, 
or other limited circumstances as determined by law and recognized by the related government organ" do not exist. Otherwise, "the decision is not enforceable". The drafting process of this policy has been finalized by the end of 2009 and the draft policy was handed over to the Afghan Minister of Justice. In order to reach any legal binding effect, the policy must be further elaborated by the Taqnin 61 and then transferred into a national law. The urgency of implementing the national policy was even mentioned in Communiqués of the London Conference in January 2010 and the Kabul Conference in July $2010 .^{62}$ A first draft of the law has been recently written, however it is currently discussed among both international and national actors involved, facing oppressions especially from human rights organisations and the Supreme Court ${ }^{63}$. Having a brief look at the current version of the law, some issues become apparent. First of all the legislator must ensure that the new law does not violate Article $122 \mathrm{AC}$, forbidding the submission of jurisdiction to any organ except of those mentioned in the constitution. Pursuing Article 116 para. $2 \mathrm{AC}$, those justice institutions are the Supreme Court, Courts of Appeal and Primary Courts, as well as special courts dealing with certain crimes related to the president or (Article 69 AC), ministers (Article 78 AC) or members of the Supreme Court (Article 127 AC). However, the Afghan Constitution does not mention any informal mechanisms as being authorized to perform jurisdiction.

Another problem is the handling of crimes, especially minor crimes. Some argue in favour of referring such crimes to a jirga, especially when they have been committed by juveniles. The authorization of a jirga to punish the offender however would be a violation of Article 27 (3) AC, stating that no one shall be punished without the decision of an authorized court and on the basis of the law. When it comes to the determination of the jirga's competencies, the legislator must take care not to mix arbitration and mediation. This is especially valid for handling minor criminal cases. Extrajudicial settlement of such cases also exists in other national legal systems, for example the German "Täter-OpferAusgleich" "64. A similar procedure established in the jirga system however would be mediation and not arbitration. The difference between arbitration and mediation is that a mediator tries to find a solution together with the parties. However it is mainly the disputing parties who negotiate the settlement with the support of the mediator, whereas in an arbitration procedure the arbitrator(s) give determination in terms of liability or compensa-

62 See Paragraph 22 of the London Conference Communiqué and No. 9 Kabul International Conference on Afghanistan Communiqué.

63 Personal Interview on 11 October 2010 in Heidelberg.

64 The "Täter-Opfer-Ausgleich" (TOA) can only be applied in minor criminal cases and only if both parties have agreed to such a procedure. In the TOA, victim and offender together with a mediator negotiate the form of compensation for the victim. If the TOA is successful, the prosecutor can even abandon the criminal proceedings against the offender. 
tion after hearing the case. The current draft law does not seem to make such a differentiation between the two procedures.

Finally, the legal drafters must bear in mind the realities in Afghanistan. Any attempt to structure a jirga will fail, if the actual distribution of power is not taken into consideration. It might be helpful for the disputing parties, if the members of a jirga have knowledge about the "laws of the country and proper local traditions" as the current draft law envisages, and the decision is based on such. However the implementation of such provision will fail if it violates the local power structures by excluding any power holder from the decision making process.

A more detailed analysis of the law however will only be reasonable, when the final draft was finally approved by the President and the Parliament, which probably takes some more time ${ }^{65}$.

Apart from the discussions on the legal basis for a linkage between formal and informal justice several projects are currently underway, aiming on strengthening such a linkage and exploring ways that the new law could potentially be implemented on the ground. Since there is no common status quo throughout the country, each single district has to be evaluated in advance and thus the projects depend on the special circumstances of each district. Due to the aggravation of the security situation, especially in the Southern and Eastern parts of the country, such evaluation missions are often difficult to realize.

\section{Conclusion}

Building a thoroughly organized and well-functioning justice system in Afghanistan still faces many challenges and needs patience. While in the last years not much attention has been paid to the rule of law sector - compared to other sectors - the importance of a stable environment established on a functioning legal system got more and more in the focus of the international donor community.

Although the informal justice sector might be more consistent with the Afghan traditions and values, in some cases the application of customary law in fact violates international and constitutional fundamental rights, especially in regard to women's rights, fair trial principles and the punishment of crimes. On the other hand, informal conflict resolution institutions do have the potential to provide justice and create stability through mediation and reconciliation. Informal justice is thus recognized as more legitimate by the majority of the Afghan people as formal justice, which normally makes decisions in favour of one party only and thus does not contribute to settle the dispute. Furthermore, as long as the formal sector remains that corrupt, expensive, slow and difficult to access, the situation will not improve in the future.

However, efforts should not only be made in regard to creating a linkage between the formal and informal justice sector. Since such a linkage implies the gradual formalization 
of the informal sector this approach inherently bears the risk that the issues of the formal sector spill over to the informal sector, leading to a justice system which is throughout corrupt and not trustworthy. This again could give rise to a "new" informal justice system, probably controlled by insurgent groups as the Taliban.

Therefore, creating such a linkage cannot exclude continuing efforts to strengthen the formal justice as well. First and foremost higher salaries for the staff working in this sector are required as well as other efforts to fight corruption. The proceedings must be shortened and be made more affordable for everyone. People must be better informed and supported regarding the access to the formal sector. Of course, infrastructure and human resources must be better developed in order to establish an active formal justice sector all over the country $^{66}$.

Creating a linkage between formal and informal institutions only makes sense in such areas, where the formal justice sector is already strong enough for overlooking the informal institutions and their decisions' compatibility with fundamental human rights. In those areas it may be useful to support informal justice as well, for example by providing trainings in the Afghan legal system or human rights or by developing a common registration procedure of those disputes settled in the informal system. It is noteworthy however that the competencies are clearly allocated between the formal and the informal sectors and that the informal justice sector does not become a justice institution on its own but rather serves as additional mean to solve disputes in order to disburden the formal institutions. This means in practice that for example major crimes should never be solved in the informal sector, since only the State has the authority to punish in accordance with the law. In addition however, informal dispute settlement mechanisms could indeed be useful in terms of negotiating compensation. However, every outcome of an informal procedure must be in compliance with the Afghan Constitution, Afghan law, international human rights standards and Shari'a law. Therefore, the non-application of customs like bad or the exchange of girls as a form of compensation must be ensured in advance.

One should bear in mind that for decades the Afghan people managed to deal with disputes without applying any formal institution. It is therefore doubtful, if the idea of rule of law as it exists in the "Western" thinking will ever be fully established in the country. Nevertheless, there is the urgent need to improve the legal situation especially in regard to disadvantaged groups like women, children or ethnic minorities. Therefore both approaches pursued complementary, namely strengthening the formal justice on the one hand and creating a linkage between formal and informal justice on the other, seems for the moment the most reasonable solution. Any effort in this regard however must match with the circumstances of the particular districts/ regions which need to be assessed in advance. 